\title{
Effect of starter cultures on microbial and physicochemical parameters of a dry fermented poultry meat sausage
}

\author{
Sabrine EI ADAB ${ }^{1 *}$, Ines ESSID ${ }^{1,2}$ and Mnasser HASSOUNA ${ }^{1}$ \\ ${ }^{1}$ Research Unity, Food and Science Technologies-UR 04 AGR02, High Food Industries School of Tunisia, 58 Avenue \\ Alain Savary- Tunis El Khadra, 1003, Tunisia. \\ ${ }^{2}$ National Agronomic Institute of Tunisia, Department of Animal Resources, Fisheries and Food Technology, 43 Avenue \\ Charles Nicolle - Tunis-Mahrajène, 1082, Tunisia. \\ Received 21 April, 2014; Accepted 16 June, 2014
}

\begin{abstract}
The aim of this work was to study the effect of Staphylococcus xylosus and Lactobacillus plantarum on microbial and physicochemical characteristics of a dry fermented poultry meat sausage. The microbial results show that lactic acid bacteria (LAB) and coagulase negative staphylococci (CNS) represent the two predominant microflora in all stages of ripening. The number of enterobacteria decreased significantly in sausages previously inoculated respectively with $L$. plantarum and with a mixed starter cultures, due to the acidifying and antibacterial activities of lactic acid bacteria. The moisture content of control and inoculated sausages decreased in all stages of ripening which allows a good preservation and consequently, improved their shelf life. Moreover, total free amino acids content increased during ripening of dry fermented sausages. Their concentrations were higher in sausages previously inoculated with starter cultures than in control ones. The main amino acids present in all stages of ripening were aspartic and glutamic acids, arginine, glycine, threonine, alanine, tyrosine, phenylalaline, leucine and isoleucine.
\end{abstract}

Key words: Staphylococcus xylosus, Lactobacillus plantarum, ripening, dry fermented sausage.

\section{INTRODUCTION}

The demand for meat products with lower fat contents or healthier fatty acid compositions has increased in recent years due to new guidelines recommending reduced saturated fat intake and consumers' desire to lose weight
(Akesowan, 2008; Archer et al., 2004; Colmenero, 2000). Several alternative strategies have been used in the manufacture of these products, such as the substitution of red meat by skinless poultry meat. Skinless poultry

*Corresponding author: E-mail: eladab.sabrine@hotmail.fr. Tel: (+ 216) 96387707.

Author(s) agree that this article remain permanently open access under the terms of the Creative Commons Attribution License 4.0 $\underline{\text { International License }}$

Abbreviations: LAB, Lactic acid bacteria; CNS, coagulase negative staphylococci 
meat contains more protein, less fat, and less cholesterol than red meat (Hu, 2005; Ressurreccion, 2004). The protein of poultry meat is of excellent nutritional quality, and it contains all of the essential amino acids for human consumption (Varnam and Sutherland, 1995). Furthermore, the manufacture of poultry meat products usually costs less than that of similar beef and pork products (Barbut, 2002). An added benefit is that poultry meat is not restricted by most cultural and religious laws, and it is consumed by both Jews and Muslims (Deumier and Collignan, 2003).

Processed poultry meat products offered a favorable environment for the growth of pathogenic bacteria. Different strategies have been used such as fermentation to guarantee food safety and to standardize product properties. Spontaneous fermentation has been applied for thousands years mainly as method of preservation of excess foodstuff and secondarily as a way to obtain spicy and flavorful foods (Drosinos et al., 2007). In fact, during this stage, the major physical, biochemical and microbiological transformations take place such as: acidification, reduction of nitrates to nitrites, formation of nitrosomyoglobin, solubilization and gelification of myofibrillar and sacroplasmic proteins, proteolytic, lipolytic and oxidative phenomen and dehydratation (Casaburi et al., 2008). Nowadays, the use of selected starter cultures for sausage production is becoming increasingly necessary to guarantee food safety, reduce the fermentation times, extend the shelf life and enhance the organoleptic characteristics of the final product (Parente et al., 2001; Drosinos et al., 2005). Most dry fermented sausages are produced with starter cultures combination of lactic acid bacteria (LAB) and coagulase negative staphylococci (CNS) (Ammor and Mayo, 2007).

Lactic acid bacteria (LAB) play an important role in meat preservation and fermentation processes because they affect both the technological properties and the microbial stability of the final product. In fact, the use of $L A B$ is essential for carbohydrate fermentation and lactic acid generation with subsequent $\mathrm{pH}$ drop which contribute to the flavor of the final product through the formation of noticeable acidic and vinegary (acetic acid) tastes. At isoelectric $\mathrm{pH}$, muscle proteins coagulate, lose their water-holding capacity and result in the sliceability, firmness and cohesiveness of the final product. Besides, at this acidic environment ripening is favored as well as color development (Drosinos et al., 2007).

Moreover, LAB inhibits growth of spoilage and pathogenic microorganisms through the production of lactic acid and antimicrobial compounds such as bacteriocins, acetic acid, ethanol, acetoin, carbon dioxide and pyruvic acid (Albano et al., 2009). The species most used as commercial meat LAB starter cultures are Lactobacillus plantarum, Lactobacillus sakei, Lacobacillus curvatus, Lactobacillus fermentum, Lactobacillus brevis, Pediococcus pentoseaceus and Pediococcus acidilactici (Hammes, 1990; Rovira et al., 1994; Schillinger and
Lücke, 1987). Whereas, LAB are mainly responsible for acidification, CNS are associated with color and flavor development (Olesen et al., 2004; Leroy et al., 2006). CNS are Gram-positive, catalase positive cocci with antioxidant activities, preventing the formation of offflavors and rancidity and their nitrate reductase activity is important for color formation (Ravyts et al., 2010). Their proteolytic and lipolytic activities contribute to the sensory quality of fermented sausages through the generation of flavor-active compounds and their precursors, such as amino acids, free fatty acids, aldehydes, amines, ketones and alcohols (Montel et al., 1996; Leroy et al., 2006). Unfortunately, CNS are generally poorly competitive in a fermented sausage environment, resulting in poor growth and even a decrease in viability during manufacturing (Di Maria et al., 2002; Tjener et al., 2004; Casaburi et al., 2008). The species most used for the production of dry fermented sausages are Staphylococcus carnosus and Staphylococcus xylosus (Laukova et al., 2010).

In Tunisia, sausages are mainly produced from red meat. The aim of this work is to produce a skinless poultry meat sausage previously inoculated with selected starters of $L$. plantarum and S. xylosus and to study the microbial and physicochemical quality during ripening.

\section{MATERIALS AND METHODS}

\section{Bacterial strains and culture condition}

The S. xylosus and the L. plantarum strains used in this study were both isolated from a Tunisian traditional salted meat "kadid" as previously reported by Essid et al. (2007) and Essid et al. (2009). These strains were selected for having the best attributes for use as starter meat cultures (Essid et al., 2007; Essid et al., 2009). Strains of S. xylosus were cultivated in Trypton Soy Broth (Biolife, Italy) at $37^{\circ} \mathrm{C}$, whereas strains of $\mathrm{L}$. plantarum were cultivated in Man Rogosa and Sharp Broth (MRS broth) (Biolife, Italy) at $30^{\circ} \mathrm{C}$. After $24 \mathrm{~h}$ of incubation, the bacterial suspensions were centrifuged at $12000 \mathrm{~g}$ for $15 \mathrm{~min}$ (Universal, 320) and the pellets were washed with sterile distilled water and resuspended in $10 \mathrm{ml}$ of the nutrient broth (Pronadisa, Spain). Cells were harvested by centrifugation (12000 $\mathrm{g}$ for $15 \mathrm{~min}$ ) and resuspended in $5 \mathrm{ml}$ of distilled water. Finally, the number of bacterial cells in each suspension was adjusted to reach the range of $6 \log C F U / m l(\lambda=600 \mathrm{~nm}, O D=0.5$ for $L$. plantarum, $O D=0.6$ for $S$. xylosus) by using a spectrophotometer (Jenway 6305).

\section{Preparation of dry fermented sausages}

The sausage formulation included $7.5 \mathrm{~kg}$ of poultry meat $(75 \%), 2.5$ $\mathrm{kg}$ of poultry fat (25\%), $400 \mathrm{~g}$ of salt $(4 \%), 20 \mathrm{~g}$ of black pepper $(0.2 \%), 20 \mathrm{~g}$ of paprika $(0.2 \%), 100 \mathrm{~g}$ glucose $(1 \%)$ and $1 \mathrm{~g}$ of potassium nitrate $(0.01 \%)$. After chopping and mixing the ingredients, the mixture was divided into four batches $(2.5 \mathrm{~kg}$ for each batch): batch 1 , inoculated with $S$. xylosus alone; batch 2, inoculated with $L$. plantarum alone; batch 3 , inoculated with $L$. plantarum and S. xylosus and batch 4 , control without inoculation. All the samples were inoculated with about $10^{6}$ viable cells per $\mathrm{g}$ of sausages. The mixture of each batch was stuffed into artificial casings, giving approximately $500 \mathrm{~g}$ as the final mass of each sausage and then placed in a fermentation chamber (BCR, CF $1 \mathrm{~B}$, 
France). The sausages were fermented for 5 days at $24^{\circ} \mathrm{C}$ and $(80 \%) \mathrm{RH}$. After five days of processing, the temperature was decreased to $14^{\circ} \mathrm{C}$ for 23 days. For sampling, three sausages of each batch at 0 day (mix before stuffing) and after 7, 14, 21 and 28 days of ripening were taken for microbiological and physicochemical analyzes and each analysis was carried out in triplicate.

\section{Microbiological analysis}

Sausage samples $(10 \mathrm{~g})$ of each batch were homogenised with 90 $\mathrm{ml}$ of sterile peptone water (Biolife, Italy) and decimal dilutions were prepared. Mesophilic lactic acid bacteria (LAB) were enumerated on MRS Agar (Biolife, Italy) after $48 \mathrm{~h}$ incubation at $30^{\circ} \mathrm{C}$. The number of staphylococci was determined on Mannitol Salt Agar (Biolife, Italy) after incubation at $37^{\circ} \mathrm{C}$ for $48 \mathrm{~h}$. Yeasts and molds were enumerated on Sabouraud Dextrose Agar (Biokar, France) at $28^{\circ} \mathrm{C}$ for 4 days.

Total viable counts were determined on Standard Plate Count Agar (PCA) (Biolife, Italy) at $30^{\circ} \mathrm{C}$ for $48 \mathrm{~h}$. Enterobacteriaceae were determined on Violet Red Bile Glucose (VRBG) (Biokar, France) at $37^{\circ} \mathrm{C}$ for $24 \mathrm{~h}$.

\section{Physicochemical analysis}

\section{$\mathrm{pH}$, moisture and weight loss}

The $\mathrm{pH}$ values were measured in homogenates prepared by blending $10 \mathrm{~g}$ of sausage (Moulinex DPA141, France) with $50 \mathrm{ml}$ of distilled water for $2 \mathrm{~min}$. Measurements were taken with a $\mathrm{pH}$ meter (Microprocessor pH meter BT-500, BoecoGermany). The moisture percentage was calculated by weight loss experimented by the sample $(5 \mathrm{~g})$ maintained in an oven (Memmert, UL 60) at $105^{\circ} \mathrm{C}$, until constant weight according to the ISO recommended method (ISO, 1973). Weight loss was expressed as a percentage of the initial weight (Liaros et al., 2009).

\section{Color measurement}

Color measurements were carried out using a CR-300 colorimeter (Minolta Chroma Meter CR-300, Japan). Each sausage was cut and the color of the slices was measured three times for each analytical point $L^{*}, a^{*}$ and $b^{*}$ scale coordinates were obtained: $L^{*}$ (lightness), $a^{*}$ (redness) and $b^{*}$ (yellowness). Before each series of measurements, the instrument was calibrated using a white ceramic tile.

\section{Free amino acids content (FAA)}

The content of FAA was determined by reverse phase HPLC. The amino acids were extracted after hydrolysis of meat proteins in the presence of concentrated hydrochloric acid. Thus, $5 \mathrm{~g}$ of dry fermented sausages were chopped and added to $4 \mathrm{ml}$ of $\mathrm{HCl} 37 \%$ $(6 \mathrm{M})$. The mixture was homogenized and then placed in an oven at $105^{\circ} \mathrm{C}$ for $24 \mathrm{~h}$. Hydrolysis was stopped by adding approximately 6 $\mathrm{ml}$ of $\mathrm{NaOH}(6 \mathrm{~N})$. Then, the mixture was filtered through a syringe filter and the filtrate was stored at $4^{\circ} \mathrm{C}$ until injection. The separation of the protein fraction of sausages was performed using HPLC Agilent L 100 system, on a column C18 $(250 \mathrm{~mm} \times 4.6 \mathrm{~mm}$ dimensions of the column, $5 \mu \mathrm{m}$ porosity). This system contains: high pressure pump, an automatic injector FLD, FLD detector and control software and acquisition of data Chemstation. The separation was carried out for $30 \mathrm{~min}$, the flow rate of the mobile phase is $1 \mathrm{ml} / \mathrm{min}$. The excitation was at $340 \mathrm{~nm}$ and the emission was at $440 \mathrm{~nm}$. The injection solution is composed of $2.5 \mu \mathrm{l}$ of the borate, buffer supplemented with $0.5 \mu \mathrm{l}$ of the sample, $0.5 \mu \mathrm{l}$ of $\mathrm{H}_{2} \mathrm{O}$ and $0.5 \mu \mathrm{l}$ of $o$-phthaldialdehyde solution. The whole is mixed with $3.5 \mu \mathrm{l}$ of air. Then, everything was injected. The injection of reference amino acids allowed determining their retention times. To determine the concentration of free amino acids in different samples, straight standards have been established relating the concentration of each reference amino acid to the area of the peak obtained.

\section{Statistical analysis}

Data were statistically analyzed using one-way ANOVA procedure of SPSS ${ }^{\circledR}$ 17.0. Duncan's multiple range test were used to determine any significant difference between mean values and evaluations were based on a significance level of $p<0.05$.

\section{RESULTS AND DISCUSSION}

\section{Microbial results}

Figure 1 shows the evolution of lactic acid bacteria (LAB), staphylococci, yeasts and molds, Enterobacteriaceae and total viable counts during fermentation of starter inoculated and control sausages. Our results show that the addition of selected starter cultures did not affect significantly $(p>0.05)$ the quantitative evolution of different microbial groups with the exception of staphylococci $(p<$ 0.05 ). The growth of microorganisms has been affected significantly $(p<0.05)$ by the time parameter with the exception of staphylococci $(p>0.05)$.

The concentrations of total viable counts in the first day of fermentation were 5.17, 6.53, 6.71 and $6.82 \mathrm{log}$ $\mathrm{CFU} / \mathrm{g}$, respectively for control sausages and sausages inoculated with S. xylosus, L. plantarum and mixed starter culture. During ripening, these numbers increased to reach respectively values of $8.75,8.92,8.89$ and 9.78 log CFU/g (Figure 1). The numbers of total viable counts remain significantly higher in sausages inoculated compared to those measured on control samples and this at all stages of ripening due to the prior inoculation of sausages by $S$. xylosus and $L$. plantarum. Our results are in agreement with those obtained by Drosinos et al. (2005).

Lactic acid bacteria were the dominant microflora in both control and starter inoculated sausages. This result is in agreement with other studies reporting that $L A B$ are the dominant microflora of dry fermented sausages (Casaburi et al., 2008; Albano et al., 2009; Papamanoli et al., 2003; Bolumar et al., 2006; Ambrosiadis et al., 2004). This predominance is explained by the suitability of $L A B$ to survive in meat environment and their ability to multiply rapidly during ripening (Drosinos et al., 2005). The LAB count in the first day of fermentation was $5.89 \log \mathrm{CFU} / \mathrm{g}$ for control sausages against 6.14, 7.59 and $7.35 \mathrm{log}$ $\mathrm{CFU} / \mathrm{g}$, respectively for sausages inoculated with $S$. xylosus, L. plantarum and mixed starter culture. During the first 14th days of ripening, the number of mesophilic LAB increased significantly to reach values of $8.34,8.27$, 

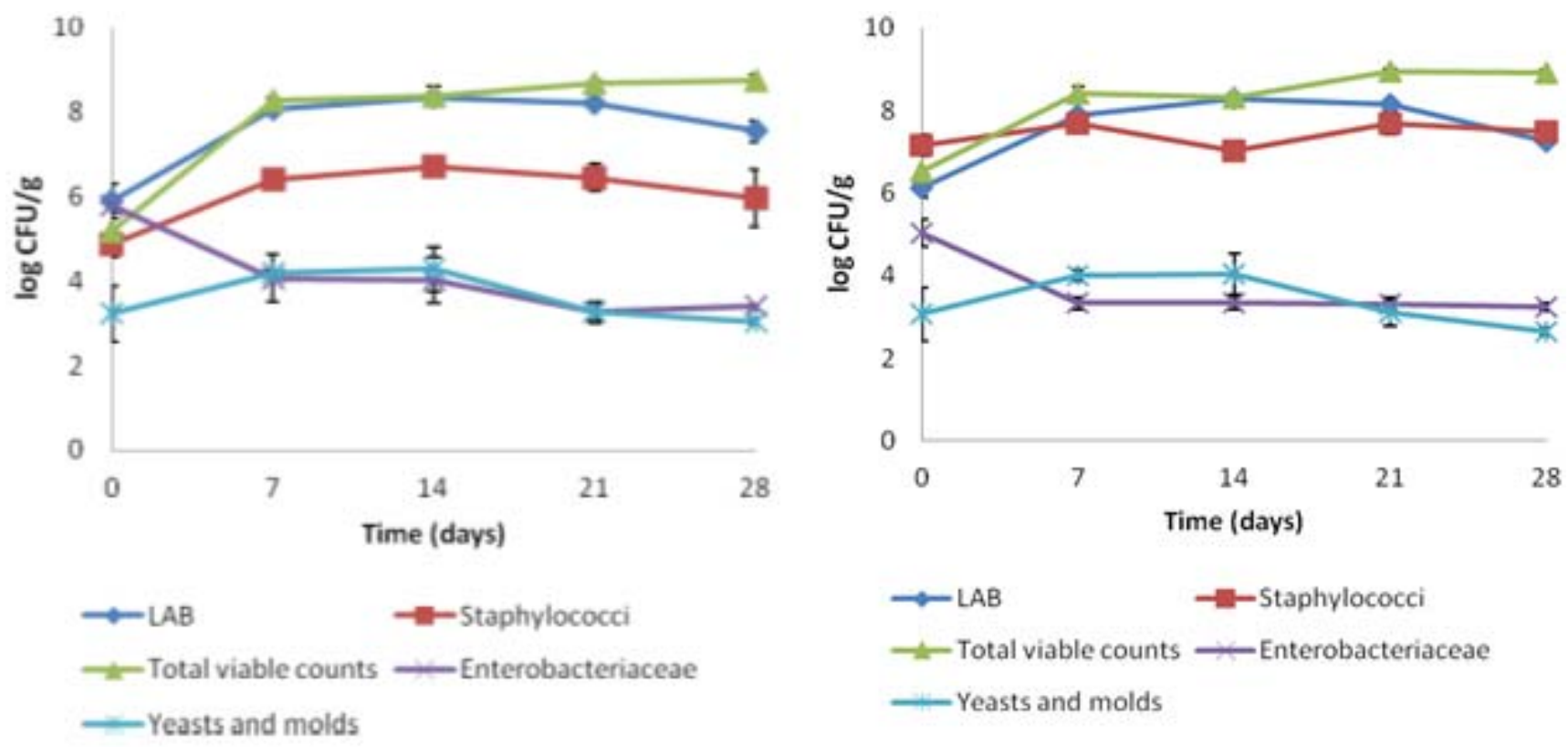

C
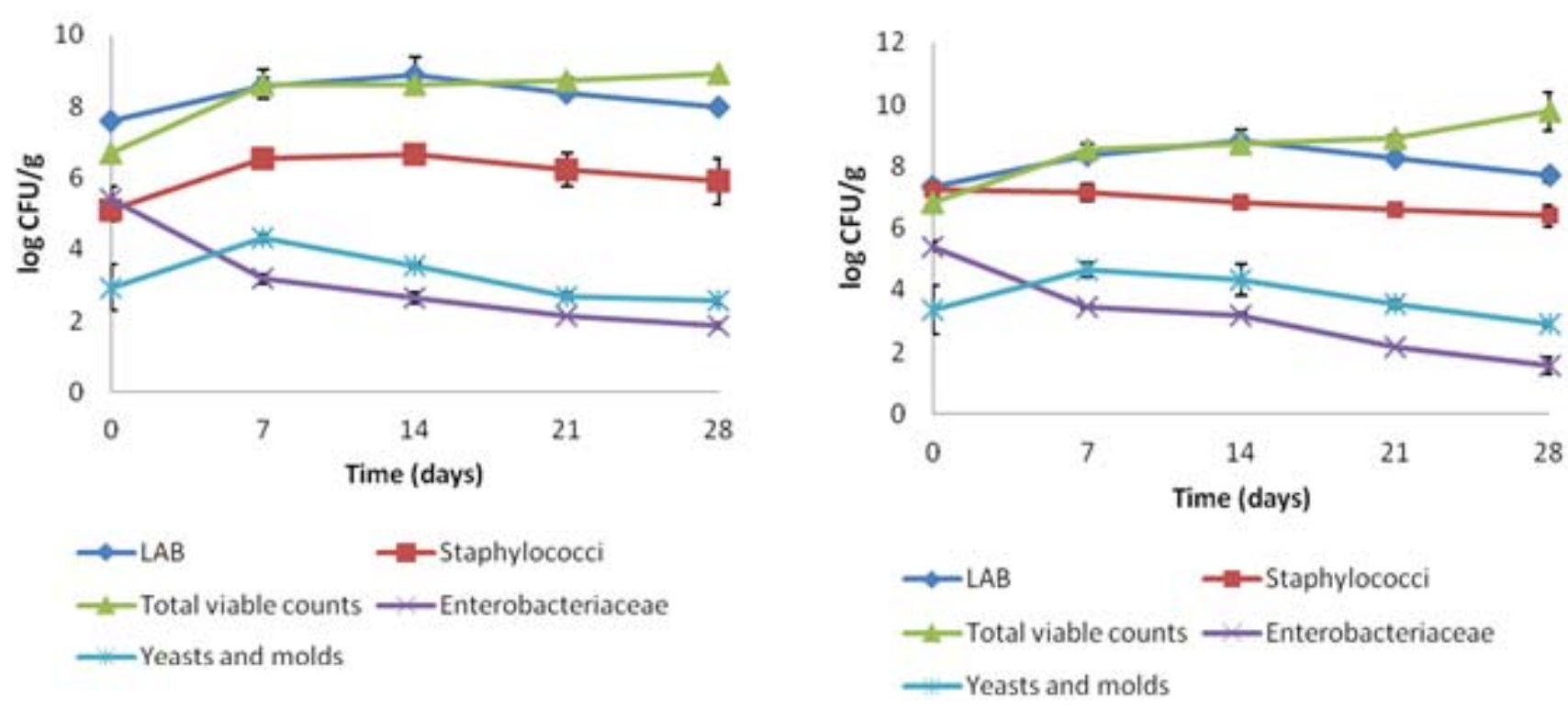

Figure 1. Evolution of microbial population during the ripening of control and inoculated dry fermented sausages: C (control sausage), SX (sausage inoculated with Staphylococcus xylosus), LP (sausage inoculated with Lactobacillus plantarum), SX + LP (sausage inoculated with mixed starter culture Staphylococcus xylosus and Lactobacillus plantarum).

8.88 and $8.82 \log \mathrm{CFU} / \mathrm{g}$, respectively for control sausages and sausages inoculated with S. xylosus, $L$. plantarum and mixed starter culture. Beyond the 14th day, the number of LAB decreased slightly (Figure 1) due to the exhaustion of the sugar (Fernandez-Lopez et al., 2008).

Staphylococci are the dominant microflora next $L A B$ in both control and inoculated sausages. This result is in agreement with many other studies reporting that LAB and staphylococci are the dominant microflora of dry fermented sausages (Casaburi et al., 2008; Rubio et al., 2007). The numbers of staphylococci remain significantly higher in sausages respectively inoculated with $S$. xylosus and mixed starter culture compared to those measured on control samples and samples inoculated with only $L$. plantarum strains. The number of staphylococci increased in control samples and sausages inoculated with $L$. plantarum during the two first weeks of 


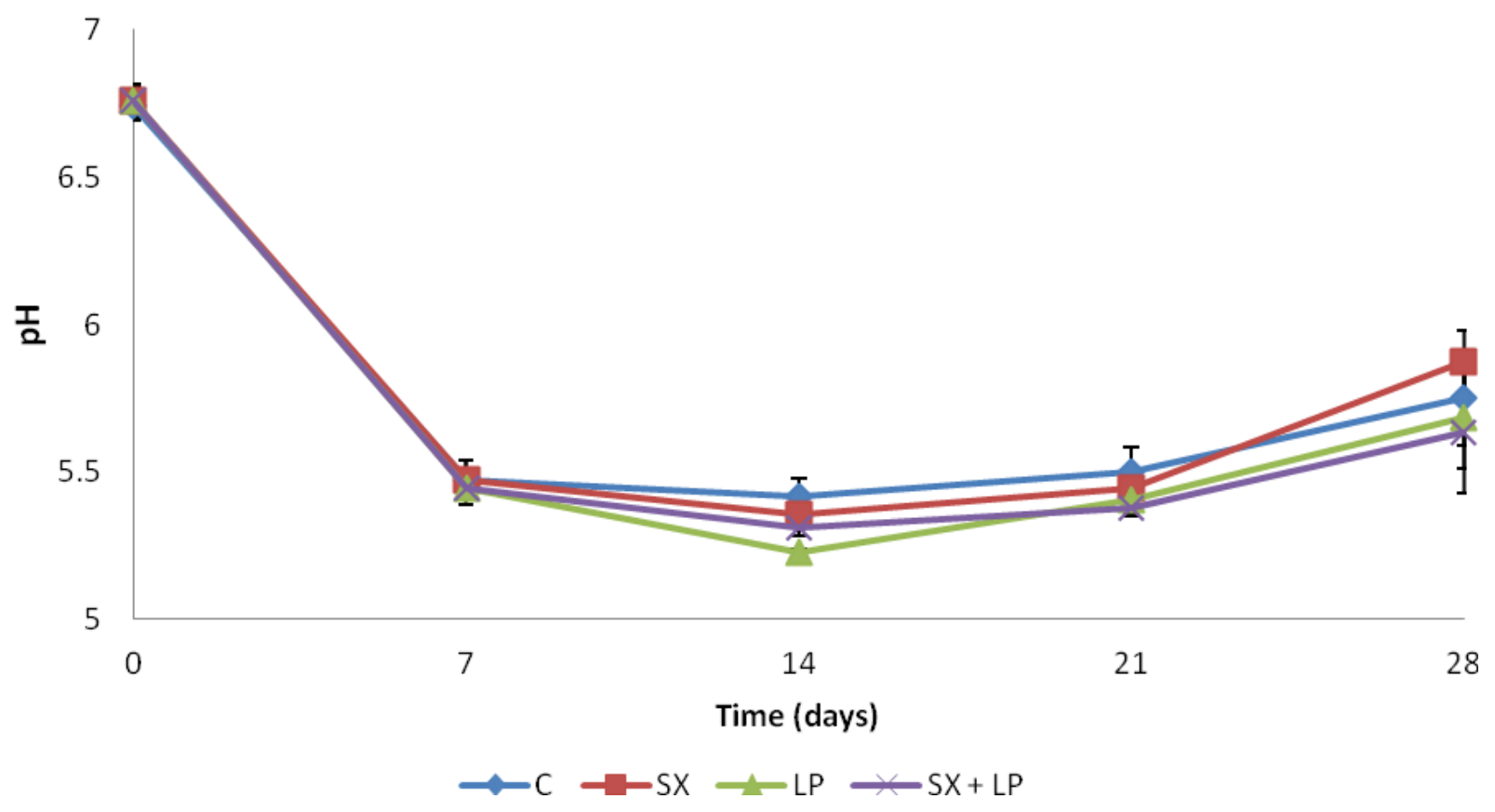

Figure 2. Evolution of $\mathrm{pH}$ during the ripening of control and inoculated dry fermented sausages: $\mathrm{C}$ (control sausage), $\mathrm{SX}$ (sausage inoculated with Staphylococcus xylosus), LP (sausage inoculated with Lactobacillus plantarum), SX + LP (sausage inoculated with mixed starter culture Staphylococcus xylosus and Lactobacillus plantarum).

ripening to reach, respectively at 14 th day 6.72 and 6.65 log CFU/g against 7.02 and $6.82 \mathrm{log}$ CFU/g, values measured on samples inoculated respectively with $S$. xylosus and mixed starter culture (Figure 1). The number of staphylococci decreased steadily at the end of ripening and this for all samples of sausages. This inhibition of staphylococci is due to the decrease of $\mathrm{pH}$ caused by lactobacilli as reported by other authors (Johansson et al., 1994; Lizaso et al., 1999; Samelis et al., 1998).

The number of Enterobacteriaceae decreased during the ripening phase of control and inoculated dry fermented sausages (Figure 1). In fact, during the ripening of sausages inoculated with $L$. plantarum and mixed starter culture, this group showed a strong decrease $(99.9 \%)$ and reached the level of 1.87 and $1.57 \log$ $\mathrm{CFU} / \mathrm{g}$, while, in the control samples and samples inoculated with $S$. xylosus, this group reached the level of 3.39 and $3.24 \log$ CFU/g at the end of ripening $(p<0.05)$. Our results are in agreement with other studies reporting that the sausages inoculated with starter cultures have the lowest number of Enterobacteriaceae than in control ones (Casaburi et al., 2008; Papamanoli et al., 2003; Rubio et al., 2007). The reduction of the number of viable cells of Enterobacteriaceae is attributed first of all, to the acidification activity of LAB that plays an important role in the inhibition of spoilage and pathogenic microorganisms (Bronomo et al., 2008; Deumier and Collignan, 2003) and secondly, to the antimicrobial compounds excreted by LAB (Ammor and Mayo, 2007; Deumier and Collignan, 2003).
Finally, the number of yeasts and molds increased steadily during the first seven days of maturation and this for all samples of sausages. Then, their concentrations decreased especially in the last two weeks of ripening to reach at 28th day values of $3.03,2.65,2.55$ and $2.91 \mathrm{log}$ $\mathrm{CFU} / \mathrm{g}$, respectively for control samples and sausages inoculated with S. xylosus, L. plantarum and mixed starter culture (Figure 1). Our results are in agreement with those obtained by Casaburi et al. (2008) who found that the number of molds and yeasts in control and inoculated sausages increased during the first days of ripening and then underwent a reduction to reach at the end of maturation values between $10^{2}$ and $10^{3} \mathrm{CFU} / \mathrm{g}$.

\section{$\mathrm{pH}$, moisture and weight loss}

The $\mathrm{pH}$ values underwent a rapid reduction in control and inoculated sausages from $6.74 \pm 0.05$ and $6.76 \pm 0.05$ to reach after 14 days of ripening $5.42 \pm 0,06,5.36 \pm 0.05$, $5.23 \pm 0.01$ and $5.31 \pm 0.03$ respectively for control samples and sausages inoculated with $S$. xylosus, $L$. plantarum and mixed starter culture (Figure 2). This drop in $\mathrm{pH}$ is due to the development of lactic acid bacteria that convert sugar added into lactic acid. During the last two weeks of maturation, $\mathrm{pH}$ of control and inoculated samples increased gradually. This increase in $\mathrm{pH}$ is explained fist of all, by the reduction of the number of LAB due to the exhaustion of the sugar and secondly, to proteolytic activity generated by microorganisms. 



Figure 3. Evolution of moisture during the ripening of control and inoculated dry fermented sausages: $\mathrm{C}$ (control sausage), SX (sausage inoculated with Staphylococcus xylosus), LP (sausage inoculated with Lactobacillus plantarum), SX + LP (sausage inoculated with mixed starter culture Staphylococcus xylosus and Lactobacillus plantarum).

Bacterial proteases induce proteolytic degradation, generating peptides, amino acids and amines which have a buffering effect on the organic acids produced by lactic acid bacteria during fermentation (Benito et al., 2007; Ruiz-Moyano et al., 2011).

Our results show that the sausages respectively inoculated with $L$. plantarum and mixture starter culture have a lower $\mathrm{pH}$ than in control sausages and sausages inoculate with S. xylosus. These results are in agreement with many other studies (Casaburi et al., 2008; Drosinos et al., 2005; Bozkurt et al., 2002) reporting that the pH of dry fermented sausage inoculated with lactic acid bacteria is lower than the $\mathrm{pH}$ of control sausage. The moisture content of control and inoculated dry fermented sausages decreased during the ripening phase (Figure 3 ). This water loss especially during the first two weeks of ripening is due first of all, to the elevated temperature of fermentation $\left(24^{\circ} \mathrm{C}\right)$ that accelerates the drying of the product and secondly, to the decrease of $\mathrm{pH}$ of sausages to their isoelectric $\mathrm{pH}$ which causes protein denaturation and thus a decrease in water retention capacity of myofibrillar proteins (Solignat, 1999).

Our results are in agreement with those of other studies (Jin et al., 2010; Casaburi et al., 2008) reporting that the moisture content of a dry fermented sausages undergoes a decrease during the ripening period. The weight of control and inoculated sausages decreased during the ripening period (Figure 4).

This loss in weight is due to the temperature of fermentation $\left(24^{\circ} \mathrm{C}\right)$ that accelerates the dehydration of the product. Our results are in agreement with other studies (Jin et al., 2010; Liaros et al., 2009) reporting that the weight loss of dry fermented sausage increases during the ripening period.

\section{Color measurement}

The color development was significantly affected by the ripening time of sausages $(p<0.05)$ and not by the addition of starters $(p>0.05)$. The quality parameters $L^{*}$, $a^{*}$ and $b^{*}$ values underwent a decrease through ripening period of different samples studied (Figure 5). Our results are in agreement with those found by Casaburi et al. (2007) and Olivars et al. (2010).

In relation to $L^{*}$ values, a decrease was observed during ripening, since sausage became darker due to weight loss (Olivares et al., 2010). With respect to $a^{*}$ values, a decrease was observed during the first two weeks of maturation, followed by a slight increase. The variation of the parameter color $a^{*}$ during ripening of dry fermented sausages is linked to the formation of a small amount of nitrosomyoglobin pigment (pink-red). Indeed chicken muscle has lower myoglobin content (Mielnik et al., 2002; Yilmaz et al., 2002).

\section{Free amino acids content}

To evaluate the effect of starter of $S$. xylosus and $L$. plantarum on proteolysis, free amino acids were determined through ripening using a chromatographic approach. The concentrations of total free amino acids during ripening are shown in Table 1. Total free amino 


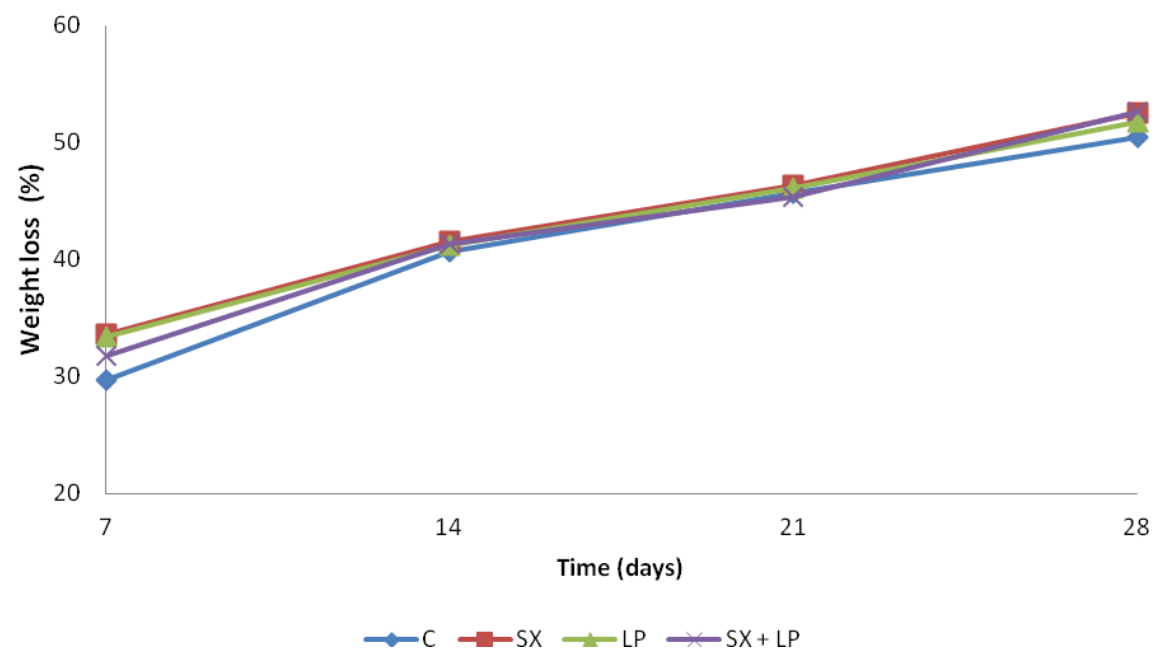

Figure 4. Evolution of weight loss during the ripening of control and inoculated dry fermented sausages: C (control sausage), SX (sausage inoculated with Staphylococcus xylosus), LP (sausage inoculated with Lactobacillus plantarum), SX + LP (sausage inoculated with mixed starter culture Staphylococcus xylosus and Lactobacillus plantarum).
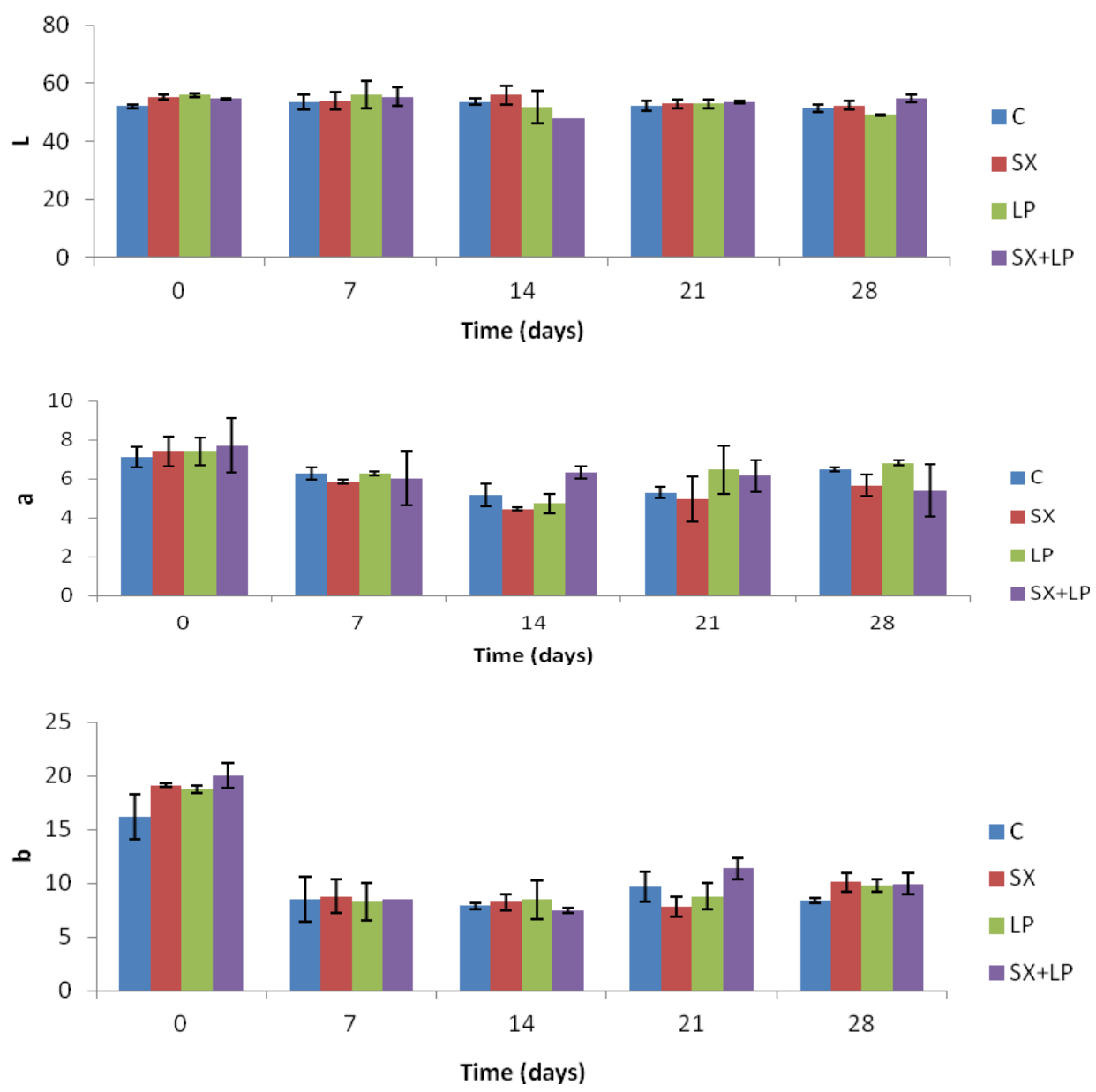

Figure 5. Evolution of $L^{*}, a^{*}$ and $b^{*}$ values during the ripening of control and inoculated dry fermented sausages: $C$ (control sausage), SX (sausage inoculated with Staphylococcus xylosus), LP (sausage inoculated with Lactobacillus plantarum), SX + LP (sausage inoculated with mixed starter culture Staphylococcus xylosus and Lactobacillus plantarum). 
Table 1. Free amino acids content $(\mathrm{mg} / \mathrm{kg})$ during the ripening of control and inoculated dry fermented sausages: $\mathrm{C}$ (control sausage), SX (sausage inoculated with Staphylococcus xylosus), LP (sausage inoculated with Lactobacillus plantarum), SX + LP (sausage inoculated with mixed starter culture Staphylococcus xylosus and Lactobacillus plantarum).

\begin{tabular}{lccccc}
\hline \multirow{2}{*}{$\begin{array}{l}\text { FAA } \\
\text { (mg/kg) }\end{array}$} & $\mathbf{5}$ & \multicolumn{4}{c}{ Time (days) } \\
\cline { 2 - 6 } & $\mathbf{0}$ & $\mathbf{C}$ & $\mathbf{S X}$ & $\mathbf{2 8}$ & $\mathbf{S X + L P}$ \\
\cline { 2 - 6 } & 109,343 & 75,104 & 106,299 & 132,328 & 99,522 \\
\hline Aspartic acid & 4,787 & 109,082 & 131,731 & 58,884 & 129,499 \\
Glutamic acid & 13,792 & 117,549 & 139,175 & 82,373 & 165,283 \\
Serine + histidine+glutamine & 130,150 & 409,206 & 454,428 & 386,513 & 593,840 \\
Arginine + glycine + threonine & 44,862 & 81,723 & 93,342 & 70,875 & 94,280 \\
Alanine & 62,041 & 18,546 & 45,443 & 84,399 & 52,675 \\
Valine + mèthionine + tryptophan & 19,936 & 3,039 & 0,482 & 19,839 & 8,296 \\
Lysine & 83,860 & 56,140 & 0,000 & 0,000 & 94,035 \\
Asparagine & 1238,607 & 1330,547 & 1603,881 & 1512,139 & 1417,612 \\
Tyrosine & 100,284 & 180,758 & 187,488 & 275,640 & 213,081 \\
Phenylalaline & 123,695 & 313,096 & 312,350 & 233,776 & 314,943 \\
Leucine & 128,465 & 251,535 & 258,091 & 420,664 & 278,008 \\
Isoleucine & 2059,822 & 2946,325 & 3332,71 & 3277,43 & 3461,074 \\
Total & & & & & \\
\hline
\end{tabular}

acids content increased significantly during the ripening phase from $2059.82 \mathrm{mg} / \mathrm{kg}$ on day 0 to $2946.32,3332.71$, 3277.43 and $3461.07 \mathrm{mg} / \mathrm{kg}$, respectively for control sausages and sausages inoculated with $S$. xylosus, $L$. plantarum and mixed starter culture. Our results are in agreement with those of many other studies (AroAro et al., 2010; Candogan et al., 2009; Casaburi et al., 2008; Lorenzo and Franco, 2012) reporting an increase in total free amino acids content during ripening of sausages. The hydrolysis of meat proteins generates polypeptides that can be further degraded to smaller peptides and free amino acids, this degradation can be produced by endogenous and microbial enzymes as reported by different authors (AroAro et al., 2010; Hughes et al., 2002). The concentrations of total free amino acids during ripening are higher in sausages inoculated than in control samples. This difference in the evolution of total free amino acids are related to the proteolytic activities of endogeneous and microbial enzymes activated by the decrease in $\mathrm{pH}$ of the medium $\left(\mathrm{pH}_{\mathrm{op}}=4.5-5.5\right)$ and by the decrease in temperature $\left(\mathrm{T}_{\mathrm{op}}=15-20^{\circ} \mathrm{C}\right.$ ) (Casaburi et al., 2008).

At the end of the ripening phase, sausages inoculated with $L$. plantarum had the highest concentrations of aspartic acid, valine, methionine, tryptophan, lysine, phenylalanine and isoleucine. While, the highest levels of serine, histidine, glutamine, arginine, glycine, threonine, alanine and leucine were observed in the samples inoculated with the mixed culture. Sausages inoculated with only S. xylosus had the highest concentrations of glutamic acid and tyrosine. Moreover, aspartic acid, glutamic acid, glycine, threonine, alanine, phenylalanine, serine, histidine, glutamine, tyrosine, leucine and isoleucine were the dominant amino acids in the four dry fermented sausages. These amino acids play an important role in development of characteristic taste and flavor of the final product (Lorenzo and Franco, 2012; Casaburi et al., 2008).

\section{Conclusion}

The use of starter cultures can improve the safety of the dry fermented sausages by the inhibition of spoilage and pathogenic microorganisms. The number of enterobacteria decreased significantly in sausages previously inoculated respectively with $L$. plantarum and with a mixed starter cultures, due to the acidifying and antibacterial activities of lactic acid bacteria. The moisture content of control and inoculated sausages decreased in all stages of ripening which allows a good preservation and consequently, improved their shelf life.

\section{Conflict of Interests}

The author(s) have not declared any conflict of interests.

\section{ACKNOWLEDGMENTS}

Special thanks to Ms. Lobna MEJRI for her help concerning the statistical analysis.

\section{REFERENCES}

Akesowan A (2008). Effect of soy protein isolate on quality of light pork sausages containing konjac flour. Afr. J. Biotechnol. 7:4586-4590. 
Albano H, Van Reenen CA, Todorov SD, Cruz D, Fraga L, Hogg T, Dicks LMT, Teixeira P (2009). Phenotypic and genetic heterogeneity of lactic acid bacteria isolated from "Alheira", a traditional fermented sausage produced in Portugal. Meat Sci. 82:389-398.

Ambrosiadis J, Soultos N, Abrahim A, Bloukas JG (2004). Physiochemical, microbiological and sensory attributes for the Characterization of Greek traditional sausages. Meat Sci. 66:279287.

Ammor MS, Mayo B (2007). Selection criteria for lactic acid bacteria to be used as functional starter cultures in dry sausage production: An update. Meat Sci. 76:138-146.

Archer BJ, Johnson SK, Devereux HM, Baxter AL (2004). Effect of fat replacement by inulin or lupin-kernel fibre on sausage patty acceptability, post-meal perceptions of satiety and food intake in men. British J. Nutri. 91:591-599.

AroAro JM, Nyam-Osor P, Tsuji K, Shimada KI, Fukushima M, Sekikawa M (2010). The effect of starter cultures on proteolytic changes and amino acid content in fermented sausages. Food Chem. 119:279-285.

Barbut S (2002). Poultry products processing. An industry guide. (1st ed.). London: CRC Press.

Benito M, Martin A, Aranda E, Perez-Nevado F, Ruiz-Moyano S, Cordoba MG (2007). Characterization and selection of autochthonous lactic acid bacteria isolated from traditional Iberian dry-fermented sausage Salchichon and chorizo sausages. J. Food Sci. 72:193-201.

Bolumar T, Sanz Y, Flores M, Aristoy MC, Toldra F, Flores J (2006). Sensory improvement of dry-fermented sausages by the addition of cell-free extracts from Debaryomyces hansenii and Lactobacillus sakei. Meat Sci. 72:457-466.

Bozkurt H, Erkmen O (2002). Effects of starter cultures and additives on the quality of Turkish style sausage (sucuk). Meat Sci. 61:149-156.

Bronomo MG, Ricciardi A, Zotta T, Parente E, Salzano G (2008). Molecular and technologicalogical characterization of lactic acid bacteria from traditional fermented sausages of Basilicata region (Southern Italy). Meat Sci. 80:1238-1248.

Candogan K, Wardlaw FB, Acton JC (2009). Effect of starter culture on proteolytic changes during processing of fermented beef sausages. Food Chem. 116:731-737.

Casaburi A, Di Monaco R, Cavella S, Toldra F, Ercolini D, Villani F (2008). Proteolytic and lipolytic starter cultures and their effect on traditional fermented sausages ripening and sensory traits. Food Microbiol. 25:335-347.

Colmenero FJ (2000). Relevant factors in strategies for fat reduction in meats products. Trends in Food Sci.Technol. 11:56-66.

Deumier F, Collignan A (2003). The effects of sodium lactate and starter cultures on $\mathrm{pH}$, lactic acid bacteria, Listeria monocytogenes and Salmonella spp. levels in pure chicken dry fermented sausage. Meat Sci. 65:1165-1174.

Di Maria S, Basso AL, Santoro E, Grazia L, Coppola R (2002). Monitoring of Staphylococcus xylosus DSM 20266 added as starter during batch fermentation and ripening of soppressata molisana, a typical Italian sausage. J. Appl. Microbiol. 92:158-164.

Drosinos EH, Mataragas M, Xiraphi N, Moschonas G, Gaitis F, Metaxopoulos $\mathrm{J}$ (2005). Characterization of the microbiol flora from a traditional Greek fermented sausage. Meat Sci. 69:307-317.

Drosinos EH, Paramithiostis S, Kolovos G, Tsikouras I, Metaxopoulos I (2007). Phenotypic and technological diversity of lactic acid bacteria and staphylococci isolated from traditionally fermented sausages in southern Greece. Food Microbiol. 24:260-270.

Essid I, Ben Ismail H, Ben Hadj Ahmed S, Ghedamsi R, Mnasser H (2007).Characterization and technological properties of Staphylococcus xylosus strains isolated from a Tunisian traditional salted meat. Meat Sci. 77:204-212.

Essid I, Medini M, Hassouna M (2009). Technological and safety properties of Lactobacillus plantarum strain isolated from a Tunisan traditional salted meat. Meat Sci. 81:203-208.

Fernandez-Lopez J, Sendra E, Sayas-Barbera E, Navarro C, PerezAlvarez JA (2008). Physio-chemical and microbiological profiles of " Salchichon " (Spanish dry-fermented sausage) enriched with orange fiber. Meat Sci. 80:410-417.

Hammes WP (1990). Bacterial starter cultures in food production. Food
Biotechnol. 4:383-397.

Hu FB (2005). Protein, body weight, and cardiovascular health American J. Clinic. Nutri. 82:242-247.

Hughes MC, Kerry JP, Arendt EK, Kenneally PM, McSweeney PLH, O'Neill EE (2002). Characterization of proteolysis during the ripening of semi-dry fermented sausages. Meat Sci. 62:205-216.

ISO (1973). Meat and meat products - Determination of moisture. ISO 1442-1973 (E)

Jin G, Zhang J, Yu X, Zhang Y, Lei Y, Wang J (2010). Lipolysis and lipid oxidation in bacon during curing and drying-ripening. Food Chem. 123:465-471.

Johansson G, Berdague' JL, Larsson M, Tran N, Borch E (1994). Lipolysis, proteolysis and formation of volatile components during ripening of a fermented sausage with Pediococcus pentosaceus and Staphylococcus xylosus as starter cultures. Meat Sci. 38:203-218.

Laukova A, Simonova M, Strompfova V (2010). Staphylococcus xylosus $\mathrm{SO} 3 / 1 \mathrm{M} / 1 / 2$, bacteriocin-producing meat starter culture or additive. Food Control. 21: 970-973

Leroy F, Verluyten J, De Vuyst L (2006). Functional meat starter cultures for improved sausage fermentation. Food Microbiol. 106:270-285.

Liaros NG, Katsanidis E, Bloukas JG (2009). Effect of ripening time under vacuum and packaging film permeability on processing and quality characteristics of low fermented sausages. Meat Sci. 83:589598

Lizaso G, Chasco J, Beriain J (1999). Microbiological and biochemical changes during ripening of salchichon, a Spanish dry cured sausage. Food Microbiol. 16:219-228.

Lorenzo JM, Franco D (2012). Fat effect on physio-chemical, microbial and textural changes through the manufactured of dry-cured foal sausage lipolysis, proteolysis and sensory properties. Meat Sci. 92:704-714.

Mielnik MB, Aaby K, Rolfsen K, Ellekjær MR, Nilsson A (2002). Quality of comminuted sausages formulated from mechanically deboned poultry meat. Meat Sci. 61:73-84.

Montel MC, Reitz J, Talon R, Berdagué JL, Rousset-Akrim S (1996). Biochemical activities of Micrococcaceae and their effectson the aromatic profiles and odours of a dry sausage model. Food Microbiol. 13:489-499.

Olesen PT, Stahnke LH (2004). The influence of environmental parameters on the catabolism of branched-chain amino acids by Staphylococcus xylosus and Staphylococcus carnosus. Food Microbiol. 21:43-50.

Olivares A, Navarro JL, Salvador A, Flores M (2010). Sensory acceptability of slow fermented sausages based on fat content and ripening time. Meat Sci. 86:251-257.

Papamanoli E, Tzanetakis N, Litopoulou-Tzanetaki E, Kotzekidou P (2003). Cacharacterization of lactic acid bacteria isolated from a Greek dry-fermented sausage in respect of their technological and probiotic properties. Meat Sci. 65:859-867.

Parente E, Grieco S, Crudele MA (2001). Phenotypic diversity of lactic acid bacteria isolated from fermented sausages produced in Basilicata (Southern Italy). J. Appl. Microbiol. 90:943-952.

Ravyts F, Steen L, Goemaere O, Paelinck H, De Vuyst L, Leroy F (2010). The application of staphylococci with flavour -generating potential is affected by acidification in fermented dry sausages. Food Microbiol. 27:945-954

Ressurreccion AVA (2004). Sensory aspects of consumer choices for meat and meat products. Meat Sci. 66:11-20.

Rovira J, Valverde E, Jaime I (1994). Applicación tecnológica de cultivos iniciadores en la elaboración de embutidos crudos curados. Eurocarne. 31:67-70.

Rubio B, Martinez B, Sanchez MJ, Dolores Garcia-Cachan M, Rovira J, Jaime I (2007). Study of the shelf life of a dry fermented sausage "salchichon" made from raw material enriched in monounsaturated fatty acids and stored under modified atmospheres. Meat Sci. 76:128-137.

Ruiz-Moyano S, Martin A, Benito MJ, Hernandez A, Casquete R, Cordoba MG (2011). Application of Lactobacillus fermentum HL 57 and Pediococcusacidilactici SP979 as potential probiotics in the manufacture of traditional Iberian dry-fermented sausages. Food Microbiol. 28:839-845. 
Samelis J, Metaxopoulos J, Vlassi M, Pappa A (1998). Stability and safety of traditional Greek salami-a microbiological ecology study. Int. J. Food Microbiol. 44:69-82.

Schillinger U, Lücke FK (1987). Identification of lactobacilli from meat and meat products. Food Microbiol. 4:199-208.

Solignat G (1999). Drying-Ripening. In: P. Durand (Eds.), Technology of meat and cured products Paris. pp. 278-391.

Tjener K, Stahnke LH, Andersen L, Martinussen J (2004). Growth and production of volatiles by Staphylococcus carnosus in dry sausages: influence of inoculation level and ripening time. Meat Sci. 67:447-452.
Varnam AH, Sutherland JP (1995). Meat and meat products. London: Chapman \& Hall.

Yilmaz I, Şimşek O, Işikli M (2002). Fatty acid composition and quality characteristics of low-fat cooked sausages made with beef and chicken meat, tomato juice and sunflower oil. Meat Sci. 62:253-258. 
